\title{
The Accidental Entrepreneur
}

by Gordon E. Moore

Like many other scientists and engineers who have ended up founding companies, I didn't leave Caltech as an entrepreneur. I had no training in business; after my sophomore year of college I didn't take any courses outside of chemistry, math, and physics. My career as an entrepreneur happened quite by accident.

And it ran counter to early predictions. When I was graduating from Caltech with my $\mathrm{PhD}$ in chemistry in 1954, I interviewed for jobs with several companies, one of which was Dow Chemical. Dow was interested in setting up a research laboratory in California, and they thought I might be someone they could send to headquarters in Midland, Michigan, to train to come back here in some kind of managerial role. So they sent me to a psychologist to see how this would fit. The psychologist said I was OK technically but I'd never manage anything. Dow did end up offering me a job in Midland, but the transfer back to California was no longer a part of it.

I didn't go to Midland after all, but went instead to the Applied Physics Laboratory at Johns Hopkins University, which has roughly the same relationship to Johns Hopkins that JPL has to Caltech, and where I could continue to do basic research in areas related to what I had done before. But I found myself calculating the cost per word in the articles we published and wondering if the taxpayers were really getting their money's worth at $\$ 5$ per word. Just as I was starting to worry about the taxpayers, the group I was working in was, for various reasons, breaking apart. So I decided to look for something that had a bit more of a practical bent, and at the same time see

There is such
a thing as a
natural-born
entrepreneur. . .
But the acciden-
tal entrepreneur
like me bas to fall
into the opportu-
nity or be pushed
into it.

if I could get myself back to California.

Lawrence Livermore Laboratory interviewed me and offered me a job, but I decided I didn't want to take spectra of exploding nuclear bombs, so I turned it down. Then one evening I got a call from Bill Shockley, who had gotten my name from Lawrence Livermore's list of people who had turned them down. Now, Shockley is a name that has a Caltech association. After earning his BS here in 1932 he went on to invent the transistor. He had been working at Bell Laboratories, and now he wanted to set up a semiconductor company out on the West Coast (a lot of Caltech connections here- the operation was financed by Arnold Beckman) with the idea of making a cheap silicon transistor. Shockley knew that a chemist was useful in the semiconductor business; they had chemists at Bell Labs, where they did useful things. And I was a chemist, so Shockley caught up with me. Still not an entrepreneur, I decided to join this operation.

I was employee number 18 . This was a startup operation. All of us except Shockley were young scientists, in our late twenties. I had no management experience or training. Unfortunately, neither did Shockley. He had run a research group at Bell Laboratories, but this was to be an enterprise rather than a research group, and he had no real experience in running a company. I suppose maybe I should have been suspicious when none of the people who had worked with him at Bell Labs joined his new venture, but I didn't even begin to think about that then.

Shockley was phenomenal from the point of view of his physical intuition. One of my 


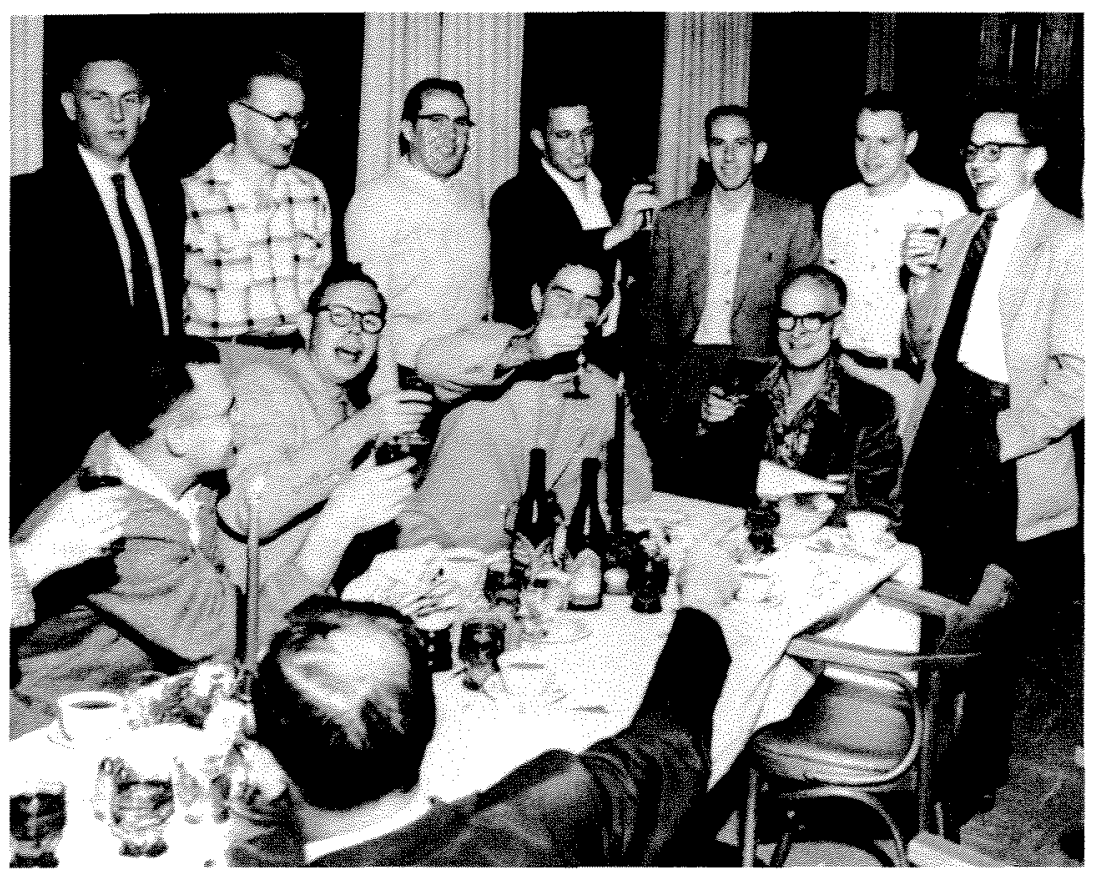

William Shockley's
employees drink a
toast to him on the
day in 1956 when he
won the Nobel Prize
for inventing the
transistor. Eight of
the crew shown here,
including Bob Noyce,
standing at center
with raised glass, and
Gordon Moore, seated
at left and turned
toward Shockley,
went off on their own
the next year and
founded Fairchild
Semiconductor
Corporation.

colleagues claimed Shockley could see electrons. He had a tremendous feeling for what was going on, say, in silicon, but he had some peculiar ideas for motivating people. For example, the company had something we dubbed the PhD production line. One day he told a group of us: "I'm not sure you're suited for this kind of a business. We're going to find out. You're going to go out there and set up a production line and run it. You know, do the operation, not direct it." This didn't go over especially well, because the group dutifully tried to operate a production line on a product that was still in the early stages of development.

He also set up a secret project. Those of us who weren't involved couldn't know what it was, although Shockley did let us know that it was potentially as important as the invention of the transistor. In such a small entrepreneurial group, having in-people and out-people created some dissension, the sort of thing that makes it hard to keep everybody working together as a team. As another illustration of his motivating skills, one day Shockley asked a group of us what we would like to do to make the job more interesting. Would we like to publish some papers? We said, "OK," so as a way of satisfying this demand he went home that night and worked out the theory of an effect in semiconductors. He came back the next day and said, "Here. Flesh this out and put your name on it and publish it." Finally, the beginning of the end, as far as morale was concerned, occurred when we had a minor problem in the company and Shockley decided that the entire staff was going to have to take lie detector tests to find out who was responsible for it.

Then he switched from his original idea of building a cheap silicon transistor to building a rather obscure device known as a four-layer diode. We viewed this with considerable concern, because some of us didn't understand exactly where the four-layer diode fit in. One day, when Arnold Beckman came around to talk to the group, Shockley made some closing remarks, just out of the blue, indicating that he could take his staff and go someplace else if Beckman wasn't enthusiastic about what was happening there. So, given all these problems, we decided that we had to go around Shockley to solve them. A group of us contacted Beckman and sat down with him through a series of dinners to try to work out a position for Shockley, in which he could give us the benefit of his technical insights but not of his management philosophy. We were thinking in terms of a professorship at Stanford. By that time, he had won a Nobel Prize, and Nobel Prize winners can get a professorship almost anywhere. What we didn't appreciate is that it's awfully hard to push a Nobel Prize winner aside. Beckman decided (as the result of advice he had received elsewhere) that he really couldn't do this to Shockley. We were told essentially that Shockley was in charge, and if we didn't like it we probably ought to look at doing something else. We felt we had burned our bridges so badly by that time that we clearly had to leave, and we started to look at alternatives. (Shockley's company held on for a few years, was acquired by Clevite Corporation, and died eventually.)

And this is where I finally became an entrepreneur. One of our group had a friend at Hayden Stone, a New York investment banking house. He wrote the friend a letter saying that there was a group of eight of us here that really enjoyed working together, but that we were leaving our current employment, and did he think that some company might like to hire all of us. The investment bankers said, "Wait a minute," and sent one of the partners, Bud Coyle, and a young Harvard MBA named Arthur Rock out from New York to visit with us. They talked to us and said: "You don't want to look for a company to hire you; you want to set up your own company." That didn't sound bad. By doing that we could stay where we were. We had all bought houses by then (they were affordable in California at that time), and we wouldn't have to move. It seemed a lot easier, so we said, "OK; fine; ler's do it," and they said they would find backing for us.

So we sat down with The Wall Street Journal, and went through the New York Stock Exchange listings, company by company, to identify which 


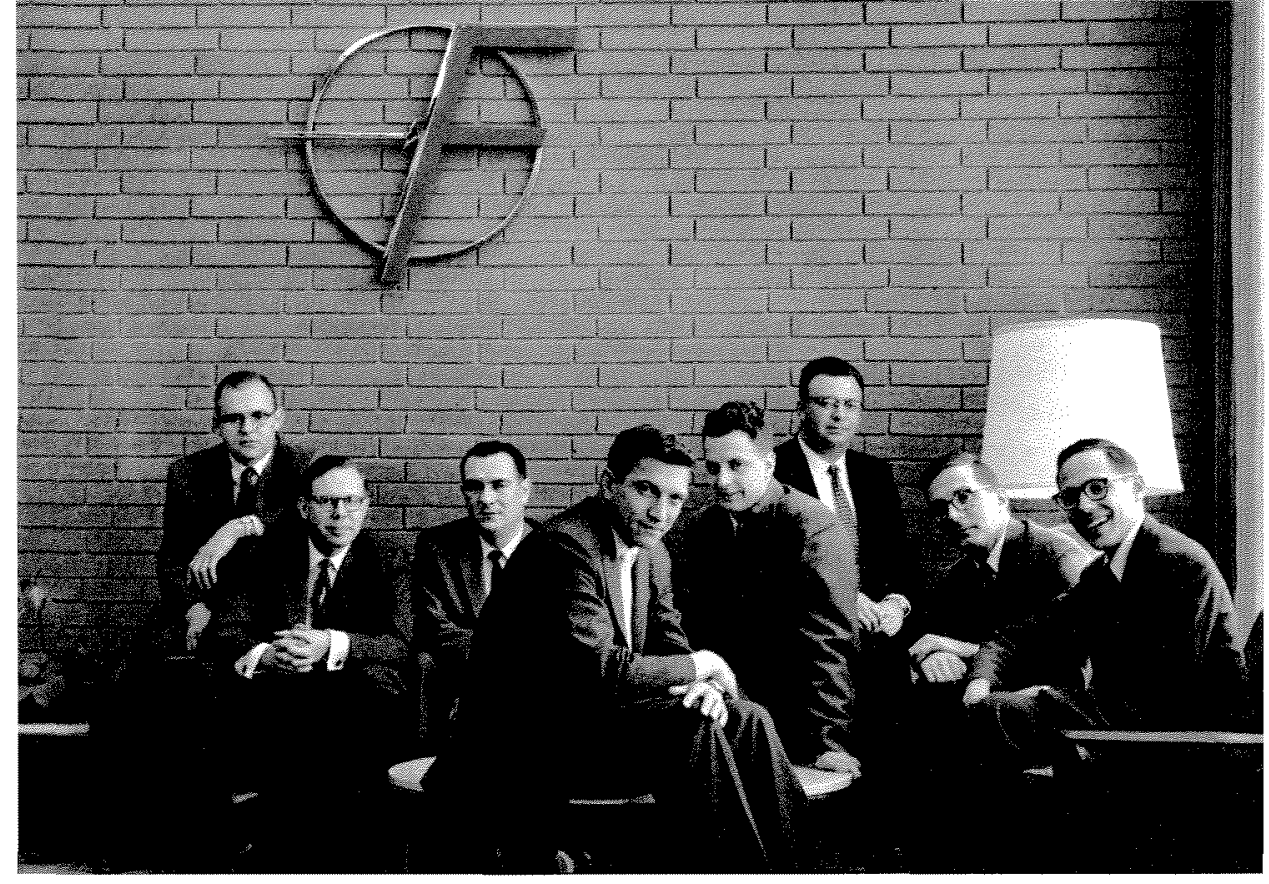

Each of the eight

of us invested

$\$ 500$ in this

startup....

Faircbild put up

some $\$ 1.3$ mil-

lion to get us

going, and we

started Fairchild

Semiconductor

Corporation.

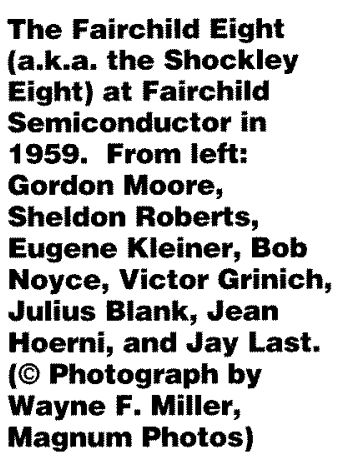

The Fairchild Elght Eight) at Fairchild

ones we thought might be interested in supporting a semiconductor venture. We identified 30some companies, and Arthur and Bud went out and contacted every one of them. They all turned it down without even talking to us. Then, quite by accident, Arthur and Bud ran into Sherman Fairchild, who happened to be a technology buff; he really loved new technology. He introduced them to the chairman of Fairchild Camera and Instrument, who was willing to take a shot at supporting this new company.

Each of the eight of us invested $\$ 500$ in this start-up. That may not sound like much now, but it was a month's salary in 1957. Fairchild put up some $\$ 1.3$ million to get us going, and we started Fairchild Semiconductor Corporation. We still weren't really quite entrepreneurs, but we had learned something along the way. We had learned from the Shockley experience that none of us knew how to run a company, so the first thing we had to do was to hire our own boss - essentially hire somebody to run the company. We advertised for a general manager. Now, when you advertise for a general manager for something like this, what you find is that every salesman in the country is convinced that be can run a company. But buried among all the responses from salesmen was one from Ed Baldwin, the engineering manager for the Hughes semiconductor operation. In the mid-fifties, Hughes was making diodes and was one of the largest semiconductor companies in the world.

Baldwin came and told us a lot of things we didn't know, so we decided that he was the right guy to bring in to run our company for us. We hired him, and he taught us a variety of things that we hadn't learned before-since most of us had not even worked for a successful manufacturing company. He taught us that the different parts of the organization should be established with different responsibilities; for example, you have to set up the manufacturing operation separate from the development laboratory. You have to engineer and specify manufacturing processes, which is completely different from getting something to work once in the laboratory. He even taught us that we should bring in a marketing manager, which we did. And everything was working fine: the development and preproduction engineering for our processes and first products was complete; we had a thick process-spec book that recorded all the detailed recipes; and we had interested customers. Then one day we came to work and discovered that Baldwin, along with a group of the people that he had suggested we hire, were leaving to set up a competing semiconductor company down the road. This was the first of the Silicon Valley spin-offs that we suffered.

We never really quite understood this. Baldwin had the same potential equity participation that we did; but he never invested his $\$ 500$ so he never got the stock. He didn't consider Fairchild Semiconductor his company, and since he wanted his own company, he left us. (He and his group also left with the "recipes"; eventually they had to return the copy of the spec book to us.) After our initial feelings of shock and betrayal, we sat down and discussed what we should do. Should we go out and hire another guy to come in and run the 
Literally dozens

of companies came out of the Fairchild experience. Not only did the technology come out of it, but Fairchild also served as a successful and encouraging example of entrepreneurship_the if-that-jerk-cando-it-so-can-I syndrome. company? We decided instead that we would try to go it alone with one of our own. So Bob Noyce, who was the one of us with the most semiconductor industry experience, became general manager. I took a sideways step to his previous position as director of research and development.

Besides what Baldwin had walked off with, we had a few other ideas coming along at that time. One of them was something called a planar transistor, created by Jean Hoerni, a Caltech postdoc whom Shockley had recruited. In fact, I had joined Shockley for the trip down to Pasadena to recruit him. Jean was a theoretician, and so was not very useful at the time we were setting up the original facility at Fairchild, building furnaces and all that kind of stuff. He just sat in his office, scribbling things on a piece of paper, and he came up with this idea for building a transistor with the silicon oxide layer left on top over the junctions. Where the silicon junctions come to the surface of the silicon is a very sensitive area, which we used to expose and had to work awfully hard to keep clean. Hoerni said, "Why not leave the oxide on there?" The conventional wisdom from Bell Laboratories had been that by the time you got done, the oxide was so dirty that you wanted to get rid of it. Nobody had ever tried leaving the oxide on. We couldn't try it either, because it required making four mask steps, each indexed with respect to the next with very high precision - a technology that didn't exist. Our first transistor took two mask steps, and that was a fairly significant development operation.

So we couldn't even try Jean's idea until a year and a half or so after we had gone into business. When we finally got around to trying it, it turned out to be a great idea; it solved all the previous surface problems. Then we wondered what else we might do with this planar technology. Bob Noyce came up with the two key inventions to make a practical integrated circuit: by leaving the oxide on, one could run interconnections as metal films over the top of its devices; and one could also put structures inside the silicon that isolated one transistor from the other.

Noyce and Kilby, who was at Texas Instruments, are often considered co-inventors of the integrated circuit. In fact, they did dramatically different things. Kilby built a laboratory model -a little circuit with transistors and resistorsby etching long, thin semiconductor structures, all connected by tiny wires. It really wasn't a practical production process. What Bob did was to take the idea of the integrated circuit - this planar technology - and come up with a way of building a practical device.

It turned out that the world really wanted some of these new devices, which led to some management challenges. We didn't have any idea of the magnitude of the opportunity we were dealing with. We were still a bunch of guys in a laboratory, somewhat amazed that people actually wanted to buy our products. We hadn't thought about expanding, but here again out theoretician, Jean Hoerni, had early on made a contribution by designing the layout of our facility to allow for what we presumed to be sufficient expansion - an extra furnace here, more nitrogen cylinders there. But we had little notion of the impact of our discovery. Here we had developed and engineered the first integrated circuits, the first family of logic circuits--very simple devices with simple gates and flip flops-and put them into production. I remember calling the senior people in the laboratory together and saying, "OK, we've done integrated circuits. What'll we do next?" And we started looking for all the peculiar physical effects we could find to see what now devices we could invent. We had no idea at all that we had turned the first stone on something that was going to be an $\$ 80$ billion business.

As a result of our ignorance, we sent our profits back to the parent company on the East Coast rather than asking to reinvest them in expanding Fairchild Semiconductor more rapidly. Now, it's not clear that we could have expanded a lot more rapidly even if we had tried, because there were significant limitations on the management crew we had. We were all still going through on-the-job training. We were mining an extremely rich vein of technology, but the mining company was too small to handle what was going on. The net result was what I call the "Silicon-Valley effect": every new idea that came along created at least one new company. Literally dozens of companies came out of the Fairchild experience. Not only did the technology come out of it, but Fairchild also served as a successful and encouraging example of entrepreneurshipthe if-that-jerk-can-do-it-so-can-I syndrome.

While we were learning on the job, Faitchild grew to be about a $\$ 150$ million business and some 30,000 employees by the late sixties. It was a fairly significant corporation by the time we were done. But things began to deteriotatepartly, I think, because it was controlled by an East Coast company. The West Coast tail was not very effective at wagging the East Coast dog. Fairchild developed some management problems. In fact, the board fired two chief executive officers within a six-month period, and was running the company with a three-man committee as the 


\section{When Bob and I \\ started looking \\ around for busi- \\ ness opportunities, we identified one \\ that we thought \\ would minimize \\ the advantages of \\ the established \\ companies.}

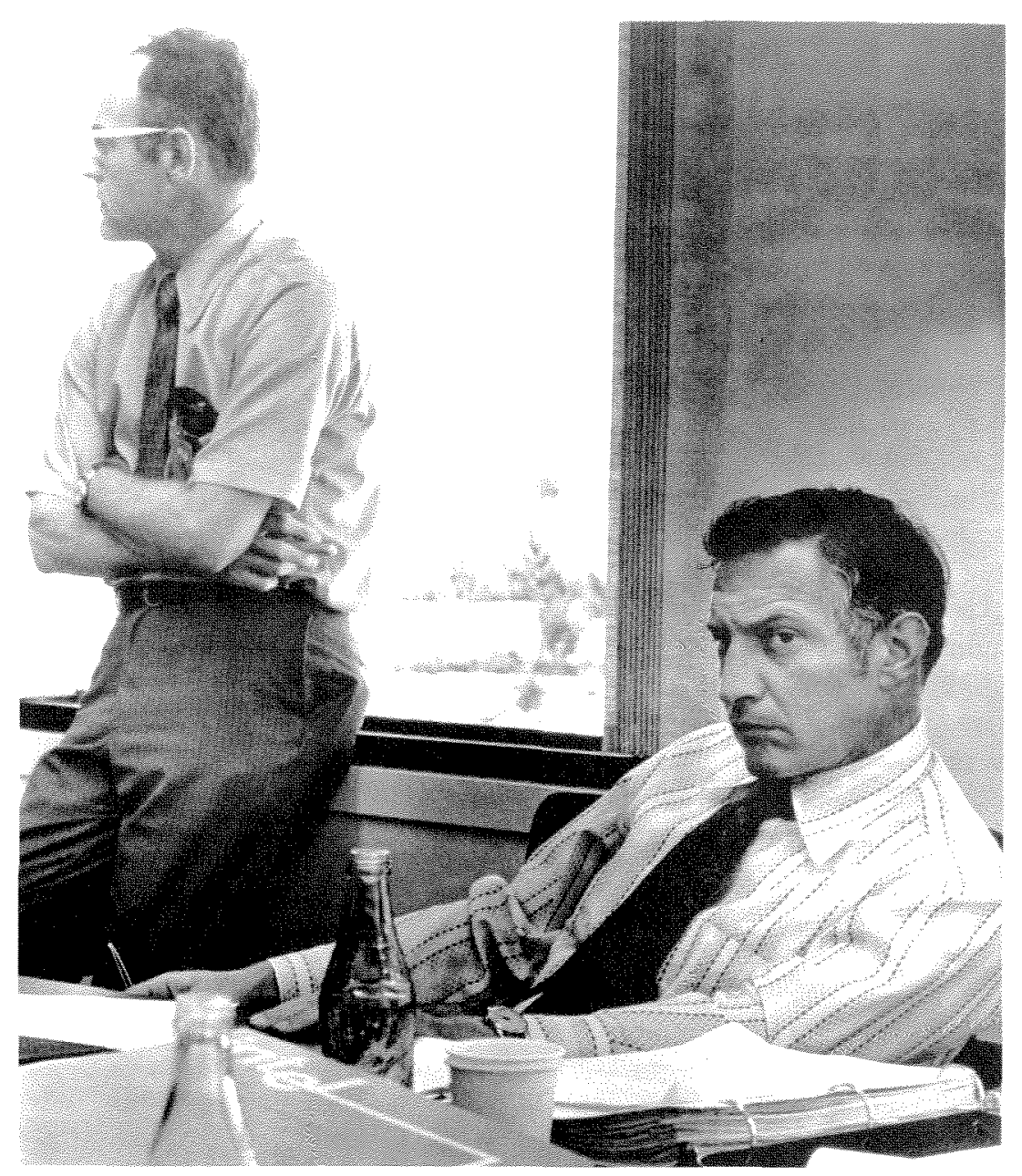

Moore (left) and

Noyce at Intel in the

early seventies.

Starting a company

wasn't always easy. board of directors. Clearly the direction of the company was going to change. When Bob Noyce (who was the logical internal candidate to become chief executive of the parent company, Fairchild Camera) saw that he would be bypassed for the job, he decided to leave. I felt that new management would probably change the nature of the company significantly. I decided I'd rather leave before any changes, than after. So the two of us set off to do something else. We had really come a long way at Fairchild. We had also made a tremendous number of mistakes, and we had squandered opportunities along the way. It was excellent on-the-job training, but there probably is a more efficient way of training entrepreneurs than by letting them make all the mistakes.

Fortunately, good products make up for a lot of problems in an organization, and I think that was what happened in our case.

When Bob and I started looking around for business opportunities, we identified one that we thought would minimize the advantages of the established companies, such as Texas Instruments, Fairchild, and the others. This opportunity was one that would change the leverage. The semiconductor industry had gotten to the point by then where having large, low-cost assembly plants in Southeast Asia was very important competitively. But technology was capable of making a more complex chip than we were capable of defining. If you identified a complex circuit function, it tended to be unique; it might be used only once in every computer, so the unit volume did not allow you to amortize the design cost. The net result was that relatively simple circuits were still being made, even as the technology continued to evolve. We thought we saw in semiconductor memory an opportunity to make a product of almost arbitrary complexity that could be used in all digital systems, and that would change the leverage from low-cost assembly back to cleverness in processing silicon. We started our business on this idea.

Now, this was at a time when venture capital was at a peak. Bob Noyce called Arthur Rock and said, "Hey, we want to set up a new company. Would you help us raise the money?" Arthur said sure, and that was the commitment of our first round of financing. We wrote a singlepage business plan. It was very general. It said we were going to work with silicon; we were going to do diffusion and other similar processes and make interesting products.

Then we started looking at technologies that would be appropriate for the business we were undertaking. In retrospect, I call it our "Goldilocks" technology strategy. We pursued three 
In 1969 Intel's 106 employees pose in front of the original plant in Mountain View, California. Noyce stands in front at left and Moore at right. Work was already under way on the microprocessor, which was invented by Intel engineer Ted Hoff (standing at right behind Moore). The world's first commercial microprocessor, Intel's 4004, shown on the opposite page, was introduced in 1971.

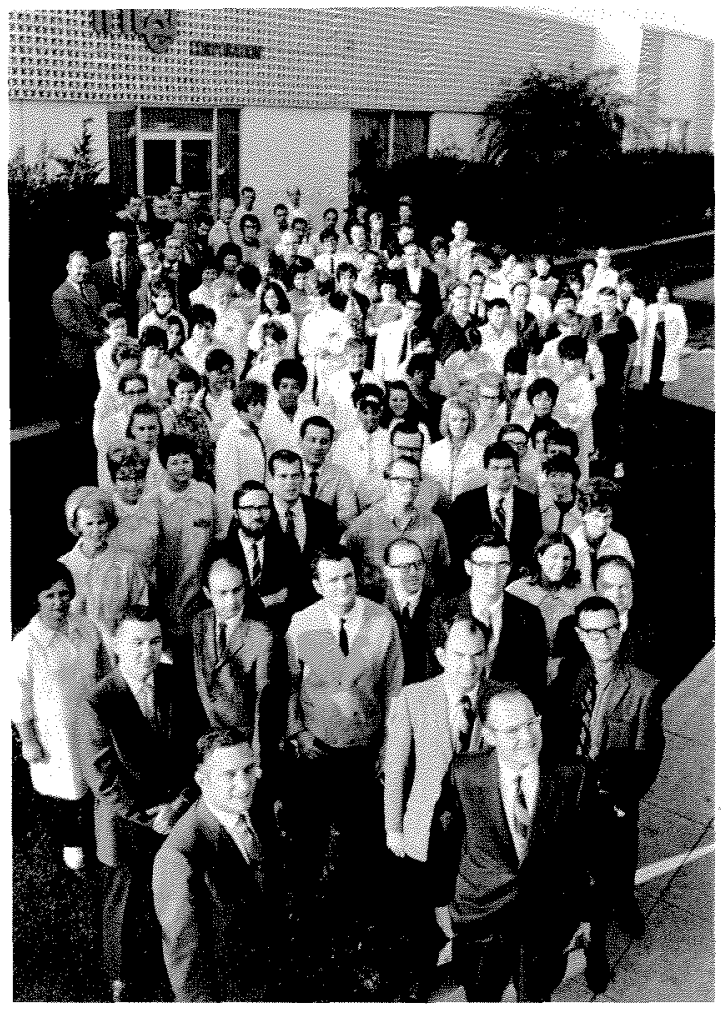

different directions. One was a particular kind of bipolar transistor, called a Schottky bipolar, that was different from what was being used then. It turned out that the technology worked just beautifully, better than anyone could have expected. In fact, it worked so well, that competitors were able to copy it rapidly. That was technology that was too easy. We chose another technology for assembling a lot of memory chips in one package-flipping them over and doing an advanced type of assembly. We're still working on that one, 25 years later. That one was too hard. Fortunately, we also chose a third one-a new version of the MOS (metal oxide semiconductor) technology called silicon-gate MOS. Here the transistor's "gate" electrode that previously was made of a metal (usually aluminum) — the $\mathrm{M}$ in MOS - was replaced by a film of silicon that had several important advantages for device switching speed and packing density on the silicon wafer surface. And that one was just right. By concentrating on this one technology and focusing our attention on a couple of difficult problems with it, we were able to solve the problems and get on with it. But the established companies that were tending their main business and doing new process development on the side, didn't have time to focus on solving the problems and took several years to get going on it. Our initial estimate was that we had five years to grow big enough to prevent the existing companies from putting us out of business. In fact, we had seven years before the big companies got into our technology. Fortunately, very much by luck, we had hit on a technology that had just the right degree of difficulty for a successful start-up. This was how Intel began.

At Intel, we decided not to make the same kind of mistakes that we had made at Fairchild. At Fairchild, for example, we used industrial distributors to sell a good portion of our products-we sold them to a distributor; the distributor sold them to the final customer. We recorded the sale when the product went to the distributor. But in our business, prices only go down. The only question is whether they go down at 20 percent per year or at 80 percent per year. Once at Fairchild, for example, when we had our distributors well stocked with our products, Motorola introduced a competitive device at a significantly lower price. To match their prices, we would have had to reverse sales revenue we had already counted and to take a terrible hit on our profit-and-loss statement, which we didn't think we could afford. So we sat there and watched our market share deteriorate while that inventory sold out. We decided we wouldn't let this happen at Intel. We don't take credit for a sale when we sell a product to our distributor, but only when it has moved off his shelves to the final customer. This was a bit of "technology" that we had to sell to our accounting firm, because it hadn't been done previously. But it turned out to solve that particular problem very well. It is now standard industry practice.

From my own point of view, I had grown very frustrated running a laboratory at Fairchild. As the manufacturing group grew more competent technically, they were less willing to listen to the people in the laboratory as the experts. So when we came up with some new idea in the laboratory - for example, stable MOS devices - we had great difficulty transferring the detailed instructions to manufacturing. We were much more effective in transferring new technology to the spin-off companies than we were internally. To avoid that problem at Intel, and to promote maximum efficiency of transfer from development to manufacturing, we decided not to set up a separate laboratory. We've set up a variety of different kinds of mechanisms and organizations along the way to make the development-tomanufacturing transfer as efficient as possible, even at a sacrifice in efficiency of either the manufacturing or the development process individually. This has minimized spin-offs, because we design our development specifically to transfer into the factory; so we don't have the problem of developing technology and ideas that we have no place for. Technology transfer is always difficult. We have tried to minimize the need to transfer it. 
From the beginning at Intel, we planned on being big. Since we had already been fairly successful at Fairchild, anything less successful in our new venture would have been a disappointment. So, at the very beginning we recruited a staff that had high potential and that we thought would be around to run the company for some time. This is an opportunity that many start-ups miss. There is no better chance to train managers than in a start-up, where they have the opportunity to see the entire company as it grows. It starts small and simple; one can see all the operations as they get bigger. I think that people looking at start-ups, venture capitalists in par-ticular, ought to push very strongly not to squander the opportunity to develop management during that time period.

We also tried to minimize bureaucracy. When we started Intel, for example, each one of us took an area of technology as his own. And instead of purchase requisitions, we gave our engineers purchase order forms, so they could work with the equipment supplier directly and just hand the salesman a purchase order. This shocked some of the vendors, but it was a very effective, no-bureaucracy way of getting going. Unfortunately, we can't do that today any more, but at the time, when we were a fairly small company, it worked very well.

Another thing we had learned along the way was to raise money before we needed it. One thing you find out after a little bit of experience as an entrepreneur is that the bank will lend you money as long as you don't need it. You can sell stock as long as you really don't have to. With good advice from directors such as Arthur Rock, we have always had plenty of capital on hand, so that we haven't been hindered in our ability to raise more.

At Fairchild we had no idea that we needed an organization - that we had to set up a manufacturing department and an engineering department and a sales force. All these things sound logical, but they take a while to figure out. And one of the most important elements in an entre-

Intel's 4004 chip, which contained 2,200 transistors, was a 4-bit microprocessor and addressed $9.2 \mathrm{~K}$ of memory (on another chip). Although this computer-on-achip began the revolution in personal computers, the company missed the boat on getting into the PC business.

\section{"What the beck \\ would anyone \\ want a computer \\ for in bis bome?"}

our revenue was $\$ 8.8$ billion, and our earnings were over $\$ 2$ billion. That puts us at least in the top 20 and maybe in the top 10 of the world's most profitable companies. We have steadily increased our lead as the largest semiconductor manufacturer and have more than 30,000 employees worldwide.

But there are some things I'm not quite so proud of that have come along with it. In 1984 , for example, we hit a peak of 26,000 employees; in 1986 we were down to under 18,000. Laying off 8,000 employees is not a very pleasant task, and it's something I think could have been avoided had Intel management been a bit more careful and perceptive.

And I can look back at a few missed opportunities. Some we missed by default. I remember talking with venture capitalist Bill Davidow, when he worked for Intel, about an engineering workstation. Intel sold something we called a "development system," which was a specialpurpose computer for the engineer. We imagined that the engineer in the future would have a single computer on his desk, and we talked about what it ought to be. But even though we talked about it, we were too darned busy doing other things, and we never got around to moving in that direction. So we missed that chance completely. I suppose I could also look at the PC as an opportunity we missed. Long before Apple, one of our engineers came to me with the suggestion that Intel ought to build a computer for the home. And I asked him, "What the heck would anyone want a computer for in his home?" (I still sometimes wonder, in spite of having a few 


\section{Most of what I learned as an entrepreneur was by trial and error, but I think a lot of this really could have been learned more efficiently.}

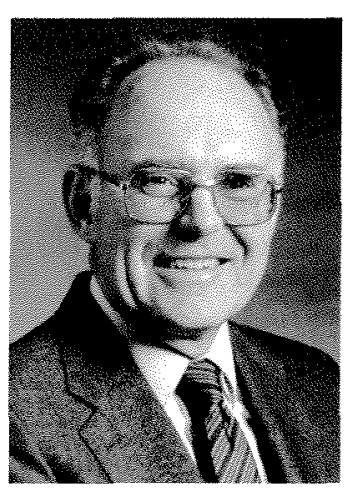

of them.) The only example he could come up with was something for the housewife to put her recipes on. I could imagine Betty at the stove cooking, poking at her computer to read the recipe. It seemed ridiculous! Well, perhaps we didn't miss that opportunity after all, because we do make a profit out of the PC business-not by being in it, but by serving it. And that may be the best way.

We missed other opportunities by poor execution. One that really bothers me is that in 1985 we were driven out of the dynamic random access memory (DRAM) business, the business in which we had made our first significant profits and which had gotten us started as a successful company. But we were driven out partly because we didn't execute a couple of generations of products very well, and partly because Japanese dumping drove us out. Different economics for the Japanese companies allowed them to run their factories and sell their products far below cost. But it still bothers me that we couldn't compete successfully in a business we had created.

Now, I don't mind missing an opportunity because we tried and failed. We took some fairly aggressive and not always successful steps toward producing computer products early in the company's life-for example, the 432 . The 432 was probably the first 32-bit microprocessor; it was hardware designed to execute object-oriented software; the hardware and software were designed together and had many advanced features. At the time that we designed the system, the technology wasn't quite ready for such complexity, and in order to get all the functionality on the chip, we had to sacrifice performance. It ended up being so slow it could do hardly anything, and we had to abandon it. But at least it was an aggressive shot—one that we just didn't target correctly.

Another shot that misfired was digital watches. We were the first company in the liquid-crystal, digital-watch business. We hoped the watch was a path to a portable digital product that could be expanded to do much more than tell time. Other companies entering the eletronic-watch market drove prices through the floor. The business opportunity we saw was completely destroyed, if it ever really existed. I still have my $\$ 15$-million watch, along with memories of Microma Watch, a division of Intel. It wakes me up in the morning; it has a good alarm system on it, and liquid-crystal displays last for at least 20 years.

In retrospect, there are a lot of things we could have done better along the way, but we did enough right to grow a fairly large company.
The world has really been changing, too, during this time period. Industry here and abroad has enjoyed huge improvements in efficiency. For example, I mentioned earlier that we had 26,000 employees in 1984. We just passed 26,000 employees again during this last year, and the company is five times as big in revenue as it was then. The competition today is a lot stronger than it was in the past. A start-up company today probably can't afford the sort of on-the-job training that we could.

There is such a thing as a natural-born entrepreneur, for whom the entrepreneurial urge drives everything and who can make a business out of almost anything. But the accidental entrepreneur like me has to fall into the opportunity or be pushed into it. Then the entrepreneurial spirit eventually catches on. To me the opportunities to start a company are few and far between. Things have to line up right. I'm not the sort of entrepreneur who can just say, "I'm going to start a company. Let's look for an opportunity." In my entire career I think I've seen only about three ideas come by that I would consider a basis on which to try to start an enterprise. But starting a company is certainly exciting, and building a successful enterprise is satisfying and rewarding.

Most of what I learned as an entrepreneur was by trial and error, but I think a lot of this really could have been learned more efficiently. I think a place like Caltech could offer an opportunity to avoid the need for trial and error in a lot of this. Broadening the education to include some instruction in business - a little bit about finance and organizations - would certainly be useful, and I think a course in this direction would probably be a significant addition to the curriculum. But a technical education is probably the best start for an entrepreneur in a high-tech business.

And it's important to remember one other thing that is essential for any entrepreneurial organization: do what you do well. Look at other things as incremental opportunities, but don't change the basis of what you do well. For Caltech, what it does well is train the best scientists and engineers in the world. My advice to Caltech is this: help students a bit if they want to move in entrepreneurial directions, but don't change the basic nature of a Caltech education.

Gordon Moore is chaiman of the board of Intel Corporation. He is also chair of Caltech's board of trustees, elected last fall to succeed Ruben Mettler. This article is adapted from a talk be gave at Caltech last March at the groundbreaking cerenonies of the Gordon and Betty Moore Laboratory of Engineering, being built with a $\$ 16.8$ million gift from the Moores. 